\title{
The Detection of a Strain of Chromobacterium lividum in the Tissues of Certain Leaf-nodulated Plants by the Immunofluorescence Technique
}

\author{
By K. A. BETTELHEIM* \\ Salmonella Reference Laboratory, Colindale, London, N.W. 9 \\ J. F. GORDON \\ Bacteriology Department, Imperial College of Science and Technology, London, S.W. 7 \\ AND JOAN TAYLOR \\ Salmonella Reference Laboratory, Colindale, London, N.W. 9
}

(Accepted for publication 19 June 1968)

\begin{abstract}
SUMMARY
An organism was isolated in pure culture from germinating seeds of Psychotria nairobiensis Brem. By standard bacteriological techniques the organism was considered to belong to the Chromobacterium lividum group. It was shown to fix nitrogen. By using an antiserum prepared against one strain, four strains were found to be serologically identical and showed some cross-reaction with Agrobacterium tumefaciens. An immunofiuorescence technique was used in a search for these organisms in the seed embryo, leaf nodules and other tissues of a number of leaf-nodulated Rubiaceae and Myrsinaceae including Psychotria nairobiensis, Ardisia crispa and a nonnodulated species of Myrsinaceae, Ardisia elliptica. From the results obtained it is concluded that this serotype of Chromobacterium lividum is present in the leaf-nodulated members of these families of plants.
\end{abstract}

\section{INTRODUCTION}

Although investigations of the organisms in leaf-nodule symbiosis of tropical Rubiaceae and Myrsinaceae species have been made for the last eighty years (von Höhnel, I882; Solereder, I899; Trimen, I894; Miehe, I9 I I $a$, $b$, 1914, I919; von Faber, 1912, I914; Boodle, 1923; de Jongh, I938; Hanada, I954; Bose, I955; Silver \& Stewart, 1962; Centifanto \& Silver, 1964) the evidence put forward by these authors leaves the identity and significance of the bacterium still undecided. It is claimed that closely similar conditions have been produced in many plant species by bacteria of different genera but in which each genus is related to a particular host.

The bacterial genus Rhizobium is known to be associated with root-nodule formation in many members of the plant family Leguminosae. In this family, plants free from bacteria may be readily obtained and successful re-infection may therefore be done. So far plants of the families Rubiaceae and Myrsinaceae have not been convincingly shown to yield plants free from bacteria; and, in each leaf-nodulated species investigated, infection has been shown to be systemic. The seeds contain bacteria which are not removed by surface sterilization. Gordon (1963) showed that seeds of Psychotria nairobiensis (Rubiaceae) heated at $50^{\circ}$ for $10 \mathrm{~min}$. and then grown under normal

* Present address: Department of Biochemistry, Imperial College, London, S.W. 7 
tropical greenhouse conditions produced not only normal leaf-nodulated plants but also crippled dwarf plants, apparently without leaf nodules. These crippled plants eventually, after 9 months observation, either reverted to normal leaf-nodulated plants or died without leaf-nodule formation. Earlier workers (von Faber, 1912, 1914; Miehe, I911 $a, b$, 1914, I919; de Jongh, 1938; Silver \& Stewart, 1962; Centifanto \& Silver, 1964) used crippled plants produced in a similar fashion for re-infection experiments, but no precautions were taken against adventitious infections, nor was it appreciated that such plants might revert to normal.

As both cultural and re-infection experiments had given inconclusive results, it was decided to use the fluorescent antibody technique for the identification and study of the bacteria in leaf nodules and other tissues of Rubiaceae and Myrsinaceae.

During the study of bacteria associated with the tissues of Psychotria nairobiensis (Rubiaceae) and Ardisia crispa (Myrsinaceae) (Gordon, 1963) bacteria provisionally placed in the family Rhizobiaceae were consistently isolated from germinating seeds. It was impossible to isolate these organisms from the leaf nodules, although they were observed there by staining techniques. The present work describes the fluorescent antibody technique to detect organisms in the various tissues of these plants and other members of the Rubiaceae and Myrsinaceae.

\section{METHODS}

Plant materials. Specimens of Ardisia crispa strain A.DC., Psychotria emetica and Pavetta grandiflora were obtained from the Chelsea Physic Garden by kind permission of $\mathrm{Mr} \mathrm{W}$. McKenzie. Psychotria nairobiensis plants were grown from seed kindly given by Dr B. Verdcourt (East African Agricultural and Forestry Research Organization, Nairobi, Kenya). P. hirtella, P. kirkii, P. capensis, Pavetta gardeniifolia, Pav. termitaria, Pav. revoluta, Pav. lanceolata and the non-nodulated $A$. elliptica were obtained from the Royal Botanic Gardens, Kew, by kind permission of the Director.

Reference bacterial cultures. The following cultures were tested as they were known to be symbionts or associated with plant diseases, or were possibly taxonomically related to our isolates. Cultures of Rhizobium leguminosarum strain 317, R. meliloti strain AH2, $R$. lupini strain LYNGBY, $R$. phaseoli strain $\mathrm{CN}, R$. trifolii strain CLF and $R$. japonicum strains B 54 and CMR I5 were obtained from the Rothamsted Experimental Station, Harpenden, Hertfordshire, by kind permission of Dr P. S. Nutman. Enterobacter aerogenes, Azotobacter vinelandii, Pseudomonas fluorescens, Agrobacterium tumefaciens strains 4 and 8, Xanthomonas begoniae and Proteus vulgaris, were obtained from the culture collection of the Bacteriology Department, Imperial College, London. Escherichia coli strain E65/56 (026. B6. H-) and Salmonella typhimurium strain SAL. 1223/67 were obtained from the Salmonella Reference Laboratory, Colindale. Klebsiella rubiacearum was obtained from the University of Florida through Dr W. S. Silver. Klebsiella sp. serotype 24 (NCTC 9144) was obtained from the National Collection of Type Cultures, Colindale, through the late Dr K. J. Steel, and Chromobacterium violaceum (NCTC 9757), C. lividum (NCTC 9796), C. typhiflavum (NCTC 938I) and Flavobacterium meningosepticum (NCTC I00I6) through Dr S.P. Lapage.

Isolation of bacterial cultures from plants. Seeds of Ardisia crispa and Psychotria nairobiensis were permitted to germinate in a moist chamber at $25^{\circ}$ for 20 days and then sterilized by $0.1 \%$ mercuric chloride, washed Io times with sterile distilled 
water and each seed was crushed in $2 \mathrm{ml}$. sterile distilled water (Gordon, 1963). These suspensions were plated on to Oxoid nutrient agar and incubated at $25^{\circ}$. After 2 days a practically pure culture of mucoid colonies often with violet pigmentation, which rapidly changed to pale yellow on subculture, was observed (Gordon, 1963). Gramnegative organisms morphologically similar to those in the colonies were seen in living plants and their seeds by microscopic examination of variously stained sections (Gordon, 1963).

The biochemical reactions of two bacterial colonies from each species of seed were investigated by using the methods of Cowan \& Steel (1965). The ability to grow on synthetic nitrogen-free medium (Gordon, 1963) was also investigated. In addition, nitrogen fixation studies were performed by Dr E. R. Roberts using ${ }^{15} \mathrm{~N}$ and a mass spectrometer, and it was found that our isolates fixed nitrogen (Gordon, 1963).

As discussed later these isolates were classified as Chromobacterium lividum; they will be referred to as 'our isolates'.

Preparation of antigens. The strain of Chromobacterium isolated from Psychotria nairobiensis was grown as a lawn on Oxoid nutrient agar plates incubated at $25^{\circ}$ for $24 \mathrm{hr}$ followed by harvesting of the bacteria in physiological saline and washing three times with saline. The bacteria were then suspended in saline and immediately prior to the addition of $0.5 \%(\mathrm{v} / \mathrm{v})$ formalin a colony count was done, showing that $4 \times 10^{8}$ bacteria $/ \mathrm{ml}$. were present.

Preparation of the antiserum. Before any inoculations blood was withdrawn from the marginal vein of the rabbit ear to give a sample of normal serum. The inoculation course consisted of increasing doses of antigen $(0 \cdot 5, \mathrm{I} \cdot 0,2 \cdot 0,4 \cdot 0 \mathrm{ml}$.) given at intervals of 5 days. These inoculations were into the marginal vein of the ear. Three days after the last injection blood was withdrawn again from the rabbit; the agglutinin titre of the serum prepared from it was rather low, therefore this antiserum was not used. A second and similar course of inoculations was given to the same rabbit, after which a higher agglutinin titre, I/160, was obtained. After the second course, two withdrawals of blood were made at 3-day intervals and the rabbit was then bled out. The serum obtained from these samples of blood was pooled and used as the source of specific antibody for all subsequent work.

Gel-diffusion studies. Soluble antigen preparations of organisms were prepared by scraping growth from a 2-day culture on nutrient agar and shaking in toluene for $\mathrm{I} \mathrm{hr}$ at $37^{\circ}$. The aqueous layer contained the antigen material used in these studies.

The tests were done on microscope slides each covered with $5 \mathrm{ml}$. agar of the following composition: $0.02 \mathrm{M}$-sodium phosphate buffer $(\mathrm{pH} 6.0), 0.01 \%(\mathrm{w} / \mathrm{v})$ sodium azide and $\mathrm{I} \cdot 2 \%(\mathrm{w} / \mathrm{v})$ Oxoid Ion agar no. 2. The slides were placed in a moist chamber at room temperature and examined daily for a week for the production of precipitin lines.

Preparation of the fluorescein isothiocyanate (FITC)-labelled specific antibody. The normal serum and the antiserum were conjugated with FITC by the method described by Taylor, Heimer, Lea \& Tomlinson (1964). Thus, from the same rabbit preinoculation and hyperimmune globulins were conjugated with FITC. Some conjugated hyperimmune serum was kept for the blocking test.

Preparation of materials for microscopic examinations. The plant tissues were immersed in $95 \%$ (v/v) ethanol in water for I min. followed by washing with agitation in sterile distilled water for $5 \mathrm{~min}$. Films of macerated plant tissues or films of pure cultures of bacteria were made on grease-free thin slides, which were dried at room 
temperature and then fixed in methanol for 10 min. After the methanol had evaporated, one drop of FITC-labelled $\gamma$-globulin was applied to each film. The slides were then incubated in a moist chamber at $37^{\circ}$ for 20 min., washed in running tap water and blotted dry.

Microscopic examinations. Most of the preparations were examined in a darkened room with a Watson Bactil microscope fitted with a dark-ground condenser, Carl Zeiss fluorescence-free immersion oil being used with this microscope, which was adapted for fluorescence microscopy as described by Taylor \& Heimer (1964). A 805Q Ilford colourless gelatin ultraviolet filter was used. The light was a $250 \mathrm{~W}$. ME/D mercury vapour compact source lamp with an OX I Chance Pilkington glass excitation filter attached.

Other preparations were examined under ultraviolet radiation with a Reichert Zetopan Universal Fluorescence Microscope fitted with a dark-ground condenser, BG I $2 / 4 \mathrm{~mm}$. excitation filter, and an orange barrier filter. A $\times 8$ eyepiece and a $\times 100$ objective (numerical aperture $I \cdot 18$ ) were used. Fluorescence-free liquid paraffin was placed between the dark-ground condenser and the slide, and Analar glycerol between the slide and objective. Other microscopic observations were made with a Gillet and Sibert Conference Microscope, with an Iodine Quartz lamp with Kohler illumination, a cardioid condenser, a $2 \mathrm{~mm}$. BG 12 primary filter and a GG 5 secondary filter of Schott glass. A $\times 5$ photo eyepiece and $\mathrm{a} \times 100$ achromat objective (numerical aperture $I \cdot 3$ ) and an iris diaphragm were used.

\section{RESULTS \\ Bacteriology}

The morphological, cultural and biochemical characters of two isolates from germinating seeds of Psychotria nairobiensis and two isolates from Ardisia crispa were identical (Gordon, 1963). All four strains had been shown to fix nitrogen by Dr E. R. Roberts.

The biochemical reactions were investigated of the following bacterial cultures: Rhizobium leguminosarum, $R$. meliloti, $R$. lupini, $R$. phaseoli, $R$. trifolii, $R$. japonicum, Chromobacterium violaceum, $C$. typhiflavum. Enterobacter aerogenes, Azotobacter vinelandii, Pseudomonasfluorescens, Agrobacterium tumefaciens, Xanthomonas begoniae, Proteus vulgaris, Escherichia coli, Salmonella typhimurium, Klebsiella rubiacearum, Klebsiella sp. serotype 24, and Flavobacterium meningosepticum. The reactions differed on numerous tests from our isolates, which most closely resembled C. lividum.

Our isolates gave the following results: Gram-negative rods $1.5-3.5 \times 0.3-0.5 \mu$, motile, capsulated. Produce violet pigment on first isolation; yellow pigment later; oxidase and catalase positive; growth range $4-30^{\circ}$, therefore psychrophilic; do not attack the following carbohydrates: fructose, glucose, trehalose, lactose, mannitol, sucrose, salicin, dulcitol, inositol, adonitol, raffinose, sorbitol, arabinose, rhamnose, xylose, inulin, glycerol, cellobiose, sorbose, starch, maltose, glycogen and galactose. Hugh and Leifson test negative. Reduce nitrate to nitrite. Utilize citrate as sole carbon source and fix nitrogen. Grow on nutrient agar. Do not grow on MacConkey agar. Do not produce indole, $\mathrm{H}_{2} \mathrm{~S}$ or urease; give negative methyl-red, Voges-Proskauer, and $\mathrm{KCN}$ tests; do not utilize malonate, liquefy gelatin, oxidize gluconate, deaminate phenylalanine, or decarboxylate arginine, lysine or ornithine; give a negative o-nitrophenyl- $\beta$-galactoside test. 


\section{Gel-diffusion studies}

Soluble antigen preparations of our four isolates were tested by gel-diffusion against antiserum. Each of the four strains produced a single precipitin line and the four lines joined, proving that all four strains were identical.

Soluble antigen preparations were also made from the bacteria listed in Table 2; all results were negative except that a faint precipitin line was produced by Agrobacterium tumefaciens which suggested an antigenic relationship between this species and our isolates.

\section{FITC-staining results}

In microscopic examinations the following criteria were used: when bacteria were strongly fluorescent and apple green in colour, specifically labelled bacteria were suspected of being present; non-specific staining was recorded for those bacteria which were non-fluorescent and dull green to grey-green in colour. These results are shown in Table $\mathbf{I}$.

Table I. Results of examination of bacterial cultures by means of fluorescent antibody staining and gel-diffusion

$\begin{array}{ccc}\text { Specific } & \text { Precipitin } \\ \text { Organism } & \text { fluorescence } & \text { line }\end{array}$

Chromobacterium lividum isolated from:

Psychotria nairobiensis A

$P$. nairobiensis B

Ardisia crispa A

A. crispa B

Agrobacterium tumefaciens 4

A. tumefaciens 8

The following gave a negative reaction in both tests: $C$. lividum (NCTC 9796), $C$. violaceum, Rhizobium lupini, $R$. meliloti, $R$. leguminosarum, $R$. phaseoli, $R$. trifolii, $R$. japonicum, Enterobacter aerogenes, Azotobacter vinelandii, Pseudomonas fluorescens, Xanthomonas begoniae, Proteus vulgaris, Escherichia coli, Salmonella typhimurium, Klebsiella rubiacearum, Klebsiella sp. serotype 24, Flavobacterium meningo-septicum, C. typhiflavum.

Two control tests were carried out on slides of the same material as that used to determine whether the fluorescent staining reaction was specific. $\gamma$-globulin was prepared from the non-immune serum, conjugated with FITC and applied to films of plant tissue; no specifically stained bacteria were observed, but some autofluorescence was seen which was identical to that obtained by using labelled specific $\gamma$-globulin.

That the labelled antibody was specific in its staining reaction of our isolates was proved by the 'blocking test' (Mellors, 1959). Plant tissue preparations similar to those used above were treated with unconjugated specific $\gamma$-globulin, then stained with labelled $\gamma$-globulin. In every case the unconjugated specific $\gamma$-globulin blocked staining by the labelled specific $\gamma$-globulin. Further tests showed that the hyperimmune $\gamma$-globulin failed to react with a wide selection of Gram-negative rod-shaped bacteria (Table I). These tests confirmed that the hyperimmune $\gamma$-globulin was specific for our isolates. Of the other organisms examined (Table I) only Agrobacterium tumefaciens reacted. These organisms were slightly stained by hyperimmune FITC-conjugated $\gamma$-globulin, suggesting an antigenic relationship with our isolates. This view was supported by the results of the gel-diffusion tests also given in Table $I$. 
Plant tissues. The following plant tissues were examined: crushed seed embryos, crushed leaf nodules, crushed flowers (Table 2). Films of these macerated tissues from nodulated and non-nodulated plants were treated with hyperimmune FITC conjugated $\gamma$-globulin; the results are shown in Table 2. In the leaf-nodulated plants $95-100 \%$ of the organisms present were stained specifically with FITC-labelled specific antiserum, showing that serotypes identical with our isolates, which we have identified as Chromobacterium lividum, were present in the nodules and all other tissues examined of the nodulated species listed in Table 2. This serotype was not seen in the nonnodulated Myrcinaceae species, Ardisia elliptica.

Table 2. Results of fluorescent staining of plant tissues

Plant tissues examined

Psychotria nairobiensis Crushed seed embryo Crushed leaf nodules

$P$. emetica

Crushed seed embryo Crushed leaf nodules

$P$. hirtella Crushed seed embryo Crushed leaf nodules Crushed flowers

P. kirkii

Crushed leaf nodules

P. capensis

Crushed leaf nodules

Pavetta gardenifolia

Crushed leaf nodules

Pav. grandiflora

Crushed leaf nodules

Crushed flowers

Pav. revoluta

Crushed leaf nodules

Pav. lanceolata

Crushed leaf nodules

Ardisia crispa

Crushed seed embryo

Crushed leaf nodules

*A. elliptica

Crushed leaves

\section{Specifically fluorescing organisms present and constituting $95-100 \%$ of all visible organisms}

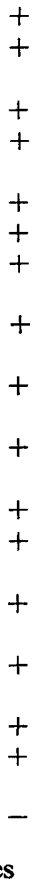

In most of the macerated plant tissues which contained specifically staining bacteria a considerable quantity of apple-green fluorescent slime was also observed. This slime was not seen in plant tissues stained according to the 'blocking test' or with labelled non-immune antiserum. It is therefore considered that this slime contains specific antigenic material produced by or originating from these bacteria. Our isolates also formed a slime in artificial media under certain conditions (Gordon, 1963). 


\section{DISCUSSION}

On the basis of the work described it is considered that the fluorescent antibody tracing technique is valuable in cases such as the present where it is difficult if not impossible to apply Koch's postulates. During the past 80 years, many different bacteria have been isolated from leaf-nodulated plants but re-infection experiments were done under conditions which allowed spontaneous reversion to nodulation to occur. Therefore it is considered that these results are open to doubt.

It has been shown that a single serotype of bacteria classified in the Chromobacterium lividum group was present in all tissues examined of the leaf-nodulated plants listed in Table 2 and that these bacteria were the bacteria observed. Because of these results it is considered that this serotype was the symbiont of the nodulated plants listed (Table 2). Further evidence was provided by the fact that the leaves of the nonnodulated member of the family Myrsinaceae Ardisia crispa did not contain any bacteria which stained with this FITC-labelled specific antibody, neither were other organisms detected using standard methods.

The biochemical reactions of our isolates show that they belong to the family Rhizobiaceae as described by Moffett \& Colwell (I968). The difficulty of distinguishing clearly between the families Rhizobiaceae and Pseudomonadaceae is discussed in their paper and they point out that the root-nodule bacteria might better be placed in the family Pseudomonadaceae. They also suggest that Chromobacterium lividum might be a separate genus. Sneath (1956) gives his results in a detailed study of the Chromobacterium group, which he divides into the mesophilic group, $C$. violaceum, and the psychrophilic group, $C$. lividum. Our isolates gave reactions identical with the latter. In the Hugh \& Leifson test prepared according to the method given in Cowan \& Steel (1965) our strains gave a negative result at $25^{\circ}$ but an oxidative reaction at $37^{\circ}$. These results were confirmed in the National Collection of Type Cultures, where ten strains of Chromobacterium lividum were also examined and it was found that two strains gave a negative reaction in Hugh \& Leifson at $25^{\circ}$ and at $37^{\circ}$.

Sneath (1956) had found that these two strains, CA and EB, gave oxidative reactions in Hugh \& Leifson's medium at $25^{\circ}$ but this is possibly due to slight differences in the ingredients of the medium.

The extensive cultural and morphological characteristics given by Gordon (1963) also agree closely with the description given by Sneath (1956) for the Chromobacterium lividum group. Bacteria of the Rhizobiaceae are often difficult to classify, particularly if found unassociated with their normal plant host (Skerman, 1967), therefore the fact that our isolates are similar to $C$. lividum makes us conclude that they belong to that group.

One of the strains isolated from Psychotria nairobiensis has been deposited in the National Collection of Type Cultures, number NCTC 10590, and one of the strains isolated from Ardisia crispa, number NCTC I059I.

We are grateful to Dr C. E. D. Taylor, Mr G. V. Heimer, Dr A. Paton, Dr A. H. Dadd, the late Dr S. E. Jacobs, the late Dr K. J. Steel for help and encouragement; to Dr S. Bascomb and Dr S. P. Lapage for making available their data on the Hugh \& Leifson reactions of our isolates and other strains of Chromobacterium; also to Mr W. Clifford and Messrs Gillet and Sibert for assistance. 


\section{REFERENCES}

Boodle, L. A. (1923). The bacterial nodules of the Rubiaceae. Kew. Bull. Misc. Inf., no. 346.

BOSE, S. R. (1955). Hereditary (seed-borne) symbiosis in Ardisia humilis Vahl. Nature, Lond. 175, 395.

Centifanto, Y. M. \& Silver, W. S. (1964). Leaf-nodule symbiosis. I. Endophyte of Psychotria bacteriophila. J. Bact. 88, 776.

Cowan, S. T. \& STeEL, K. J. (1965). Manual for the Identification of Medical Bacteria. Cambridge University Press.

FABer, F. C. voN (1912). Das erbliche Zusammenleben von Bakterien und tropischen Pflanzen. Jb. wiss. Bot. $\mathbf{5}, 285$.

FABER, F. C. VON (1914). Die Bakterien Symbiose der Rubiaceen. (Erwiderung und ergänzende Mitteilungen.) Jb. wiss. Bot. 54, 243.

GORDON, J. F. (1963). The nature and distribution within the plant of the bacteria associated with certain leaf-nodulated species of the families Myrsinaceae and Rubiaceae. Thesis, University of London.

HanadA, K. (1954). Uber die Blattknoten der Ardisia-Arten. Isolierung der Bakterien und ihre stickstoffbindende Kraft in Reinkultur. Jap. J. Bot. 14, 235.

HöHNEL, F. R. vON (I 882). Anatomische Untersuchungen über einige Secretionsorgane der Pflanzen. Sber. Akad. Wiss. Wien. Math.-Naturw. Klass. 84 (1), 583.

DE JoNGH, PH. (1938). On the Symbiosis of Ardisia crispa (Thunb.) A.DC. Thesis, University of Leyden, Holland.

Mellors, R. C. (1959). Fluorescent-antibody Method. In Analytical Cytology, 2nd ed. Ed. by R. C. Mellors. London. McGraw-Hill Book Co., Inc.

MieHE, H. (I9I Ia). Die sogenannten Eiweissdrüsen an den Blättern von Ardisia crispa A.DC. (Vorläufige Mitteilung). Ber. dt. bot. Ges. 29, 156.

MIEHE, H. (I 9 I I $b$ ). Die Bakterienknoten an den Blatträndern der Ardisia crispa A.Dc. Jav. Studien V. Abh. Math-Phys. Klasse Kön. Sächs. Ges. Wiss. 4, 399.

MIEHE, H. (1914). Weitere Untersuchungen über die Bakteriensymbiose bei Ardisia crispa. I. Die Mikroorganismen. Jb. wiss. Bot. 53, I.

MIEHE, H. (1919). Weitere Untersuchungen über die Bakteriensymbiose bei Ardisia crispa. II. Die Pflanze ohne Bakterien. Jb. wiss. Bot. 58, 29.

Moffett, M. L. \& Colwell, R. R. (1968). Adansonian analysis of the Rhizobiaceae. J. gen. Microbiol. 5I, 245.

Silver, W. S. \& Stewart, P. K. (1962). Plant-microbe symbiosis in non-legumes. 8th int. Congr. Microbiol. Montreal, Abstr. B 14-1 I.

SKERMAN, V. B. D. (1967). A Guide to the Identification of the Genera of Bacteria, 2nd ed. Baltimore: Williams \& Wilkins Co.

SNeATH, P. H. A. (1956). Cultural and biochemical characteristics of the genus Chromobacterium. J. gen. Microbiol. 15, 70.

SOLEREDER, H. (1899). Systematische Anatomie der Dikotyledonen. p. 574 Stuttgart.

TAYLOR, C. E. D. \& HeIMER, G. V. (I964). Rapid diagnosis of sonne dysentery by means of immunofluorescence. Br. med. $J$. ii, 165 .

Taylor, C. E. D., Heimer, G. V., LeA, D. J. \& Tomlinson, A. J. H. (ig64), A comparison of a fluorescent antibody technique with a cultural method in the detection of infections with Shigella sonnei. J. clin. Path. 17, 225.

Trimen, H. (1894). A Handbook to the Flora of Ceylon, Vol. I, p. 350. London. 